\title{
Biological assessment of contaminated shooting range soil using earthworm biomarkers
}

Jūratè Česynaitè

Vytautas Magnus university

Marius Praspaliauskas

Lithuanian Energy Institute: Lietuvos energetikos institutas

Nerijus Pedišius

Lithuanian Energy Institute: Lietuvos energetikos institutas

Gintare Sujetoviene ( $\nabla$ gintare.sujetoviene@vdu.lt)

Vytauto Didziojo Universitetas https://orcid.org/0000-0003-1138-9990

\section{Research Article}

Keywords: shooting range, lead, trace elements, toxicity, antioxidant enzyme

Posted Date: March 29th, 2021

DOI: https://doi.org/10.21203/rs.3.rs-312909/v1

License: (1) (1) This work is licensed under a Creative Commons Attribution 4.0 International License. Read Full License

Version of Record: A version of this preprint was published at Ecotoxicology on September 17th, 2021. See the published version at https://doi.org/10.1007/s10646-021-02463-w. 


\section{Abstract}

The contamination in shooting range soils is widely know ecological problem around the world. The aim of this study was to investigate the toxic effects of contaminated shooting range soil on physiological and biochemical endpoints of Eisenia fetida. A shooting range located in Alytus, Lithuania was chosen as a object to assess the site-specific soil toxicity to earthworm E. fetida . The elevated concentrations of $\mathrm{Pb}, \mathrm{Cu}, \mathrm{Fe}, \mathrm{Ni}, \mathrm{Mn}, \mathrm{Zn}$ in soil was found along with lower organic matter content and higher soil density, especially closer to the target line. Significant weight loss was observed in earthworms exposed to soil of the most contaminated shooting range site. Significantly higher concentrations of $\mathrm{Pb}, \mathrm{Cu}, \mathrm{Fe}, \mathrm{Ni}$, $\mathrm{Sb}$ was determined in the tissues of adult worms from the very end of the shooting range. No juveniles were observed in the most contaminated soil, higher concentrations of $\mathrm{Pb}, \mathrm{Cu}, \mathrm{Fe}, \mathrm{Mn}, \mathrm{Zn}$ were found in the tissues of juveniles exposed to the contaminated soil of study sites were concentrations of lead were lower compared to the most contaminated site, but higher compared to control. Exposure to contaminated soil caused antioxidant system alterations and lipid peroxidation. It was observed a compensatory mechanism between the activities of GR and glutathione S-transferase (GST) under trace elements induced toxicity.

\section{Introduction}

Contamination of the soil with toxic trace elements is becoming a serious and important dimension of environmental pollution. Anthropogenic activities such as development of industry and agriculture contribute to the increased contents of trace elements in the soil environment and potential risk to the health of organisms (Rodríguez-Seijo et al. 2017; Li et al. 2019). Shooting ranges are a potential source for contamination of soils with various trace elements since shooting activities contribute to deposition of large amounts of trace-element-based bullets (Sorvari 2011; Sanderson et al. 2018). Lead is the main bullet component (>90\%), while other elements are also present - $\mathrm{Sb}, \mathrm{Cu}, \mathrm{As}, \mathrm{Zn}$, and $\mathrm{Ni}$ (Sanderson et al. 2012, 2014; Dinake et al. 2019). During the shooting process, bullets accumulate in the ranges' soil, especially in the backstop berm soil. Concentrations of $\mathrm{Pb}$ in a shooting range soil can be up to 54000 $\mathrm{mg} \mathrm{kg}^{-1}$ (Hardisonjr et al., 2004) or even up to $100000 \mathrm{mg} \mathrm{kg}^{-1}$ (Dinake et al. 2019). Bioavailability of lead depends on solubility of solid lead phases and physicochemical soil properties. Soil pH is the primary factor contributing to bioavailability of lead because it regulates solubility and soil reactions (Fayiga and Saha 2016). Despite soil pH, increased in temperature and moisture affect the breakdown of bullets and formation of secondary minerals - higher temperature increases exchangeable and carbonate fractions of $\mathrm{Pb}$, and higher soil moisture speeds up weathering (Sanderson et al. 2012). Vegetation cover reduces lead leaching (Fayiga and Saha 2016).

Quantification of trace elements in shooting range soils has confirmed the possible hazard that heavy metals present to receptors. Contamination of shooting range soils poses a risk of trace element accumulation to higher trophic levels. Considering high contamination in the shooting range soils, these sites' ecotoxicological risks of these sites become an important field of study (Baer et al. 1995; Reid and Watson 2005; Sneddon et al. 2009; Sanderson et al. 2018; Sujetoviené and Česynaitè 2019; Dinake et al. 
2019). Contamination of hazardous trace elements results in a reduced of survival and reproduction rate of earthworms (Luo et al. 2014a; Sanderson et al. 2014), mites (Luo et al. 2015), and negatively affects all soil faunal communities (Selonen et al. 2014). While collembola (Folsomia candida) survival was not sensitive to $\mathrm{Pb}$ contamination, internal $\mathrm{Pb}$ concentrations linearly increase with increasing $\mathrm{Pb}$ concentrations in the shooting range soils (Luo et al. 2014b). Bioaccumulation of Pb in Enchytraeus crypticus was also linearly related to total soil $\mathrm{Pb}$ concentrations, and the most toxic effects to these organisms were in the most contaminated and acid shooting field soils (Luo et al. 2014c).

Changes in biochemical markers of soil fauna have been reported as consequences of soil contamination by trace elements. In response to inorganic pollutants, changes in activity of catalase (CAT), glutathione-S-transferase (GST), glutathione reductase (GR), and content of malondialdehyde (MDA) have been reported in earthworms (Maity et al. 2008; Bai et al. 2020; Li et al. 2020). Glutathione metabolism is crucial as a defense response under heavy metal poisoning ( $Ł a s z c z y c a$ et al. 2004). Antioxidative enzymes GST and GR have been previously reported as indicators of inorganic pollutants (Owagboriaye et al. 2016). Under oxidative stress, CAT is also reported as a sensitive antioxidative enzyme (Owagboriaye et al. 2016; Hu et al. 2016). Maity et al. (2008) reported that nonlethal $\mathrm{Pb}$ and $\mathrm{Zn}$ concentration activates GST and GR in earthworms Lampito mauritii might create adaptive response after long-term exposure. Bai et al. (2020) also reported variations of CAT activities and MDA content in earthworms E.fetida with increasing $\mathrm{Cd}$ and $\mathrm{Pb}$ concentrations in soil (from 1-20 mg $\mathrm{kg}^{-1}$ and 20-500 mg kg-1 , respectively). When earthworms were exposed to $\mathrm{Cd}$ alone at low doses (1-2 mg $\mathrm{kg}^{-1}$ ), CAT activity decreased, but stimulatory effects occurred with higher Cd doses. Contrary to increasing Pb dose, CAT activity also increased (Bai et al. 2020). MDA content increased with increasing $\mathrm{Pb}$ and Cd concentrations (Sinkakarimi et al. 2020; Bai et al. 2020). Łaszczyca et al. (2004) observed that in complex systems where animals are inhabiting a gradient of pollution alterations of enzyme activity are not related directly to heavy metal pollution. Although the antioxidative response describing the toxicity of trace elements alone or even mixtures is known, there is still a lack of information describing the biochemical response of earthworm to contamination of site-specific shooting range soil.

Because soil properties significantly influence the bioavailability and toxicity of trace elements, it is important to determine the extent of contamination and understand how different soil characteristics and contamination influence the ecotoxicity of shooting range soils to soil fauna (Luo et al. 2014c). The objective of this study was to investigate the toxic effects of contaminated shooting range soil on physiological and biochemical endpoints of E.fetida.

\section{Materials And Methods}

\subsection{Study site}

The studied shooting range is located in Alytus, southern Lithuania $\left(54^{\circ} 23^{\prime} 48.1^{\prime \prime} \mathrm{N}, 24^{\circ} 2^{\prime} 41.3^{\prime \prime} \mathrm{E}\right)$. The shooting activity started in 1957. It is used seasonally (April - July) and only .22Ir caliber ammunition is 
used in this shooting range. The whole range is approximately $400 \mathrm{~m}^{2}$ area, and $320 \mathrm{~m}^{2}$ is covered by vegetation dominated by grasses. The soil of the site is sandy loam.

\subsection{Soil sampling and analysis}

Soil samples were collected from the shooting field at four different distances from the firing line $(5,20$, $30,45 \mathrm{~m}$ ). At each distance two sites ( $1^{\prime} 1 \mathrm{~m}$ ) were selected for the soil sampling. At each sampling site, soil samples were taken from the corners and the center of the square from a depth of $10 \mathrm{~cm}$ using soil core. The five samples from each site were mixed to obtain a representative sample of each site. Soil samples were placed in plastic bags. In the laboratory, soil was air-dried, sieved through 2-mm mesh, and homogenized. The bullets from soils were collected after sieving and weighted. The dried samples were stored in polyethylene bags. A grassland soil near the shooting range was sampled and used as a reference soil ( $13 \mathrm{~km}$ from Alytus city, $\left.54^{\circ} 25^{\prime} 42.7^{\prime \prime} \mathrm{N} 24^{\circ} 14^{\prime} 03.8^{\prime \prime} \mathrm{E}\right)$.

Soil $\mathrm{pH}$ was determined potentiometrically in soil-water suspension at a ratio of $1: 5(\mathrm{v} / \mathrm{v})$ using a pH meter (inoLab 720, WTW). Total soil organic matter (SOM) content was determined by loss on the ignition at $550^{\circ} \mathrm{C}$ for $4 \mathrm{~h}$. Soil bulk density was determined after collection of bullets from the soil by pouring airdried soil in a measured cylinder. Soil texture was determined by sedimentation method.

The colorimetric microplate assay method to determine nitrate $\left(\mathrm{NO}_{3}{ }^{-}-\mathrm{N}\right)$ concentrations in the soil extracts was measured using the Griess reaction with $\mathrm{VCl}_{3}$ as a reducing agent (Hood-Nowotny et al. 2010). An indophenol method based on Berthelot reaction was used for the determination of soil ammonium $\left(\mathrm{NH}_{4}{ }^{+}-\mathrm{N}\right)$. The content of dissolved inorganic $\mathrm{P}$ was quantified using the malachite green method (Petitou et al. 1978). Absorbance values were measured with a microplate reader (SPECTROstar Nano, BMG LABTECH).

To determine total $\mathrm{Pb}, \mathrm{Cu}, \mathrm{Fe}, \mathrm{Ni}, \mathrm{Sb}, \mathrm{Mn}, \mathrm{Zn}$ concentrations in soil, approximately $0.5 \mathrm{~g}$ oven-dried soil samples were digested in $8 \mathrm{~mL}$ of $\mathrm{HNO}_{3}(65 \%), 5 \mathrm{~mL}$ of $\mathrm{HCL}(37 \%), 5 \mathrm{~mL}$ of $\mathrm{HF}(48 \%)$, and $3 \mathrm{~mL}$ of $\mathrm{H}_{3} \mathrm{BO}_{3}$ $(5 \%)$ in a Teflon vessel using a microwave digestion system (Milestone Ethos One, Italy). The concentration of trace elements was determined using inductively coupled plasma optical emission spectroscopy (ICP-OES, Perkin-Elmer, Optima 8000). Calibration of trace elements was made by analyzing the Quality Control Standard 21 (Perkin Elmer). Precision of analysis was estimated by the coefficient of correlation of four calibration points and was found to be 0.999 for all measured elements. For the data acquisition of the samples, a quantitative analysis mode was used. The scanning of each single sample was repeated three times to get reasonably reliable results. During measurements, care was taken to avoid memory effect and therefore a wash-out time of 1 min was used.

\subsection{Earthworm toxicity test and bioaccumulation assessment}

Toxicity tests with the earthworm species Eisenia fetida were conducted in a 28-day period according to an OECD guideline 222 (OECD 2015) using four replicate plastic boxes per tested and reference soils. These target organisms for this test were chosen because earthworms are representatives of soil fauna. 
Earthworms are an essential soil ecosystem component and important bioindicators of soil quality because of direct exposure to contaminants in soil and soil ingestion (Maity et al. 2008; Sanderson et al. 2014; Luo et al. 2014b; Bai et al. 2020). Earthworms were acclimatized for one day with the reference substrate prior to being used in the toxicity experiment at $20 \pm 2^{\circ} \mathrm{C}$. Ten mature earthworms with developed clitellum and similar in size were put into boxes containing $500 \mathrm{~g}$ of dry soil. Food availability and moisture content ( $50 \%$ of water holding capacity) were checked weekly and supplemented as needed. After 4 weeks, adult worms and juveniles were collected, washed, counted, and weighted. Samples of earthworms were frozen at $-80^{\circ} \mathrm{C}$ until use.

For trace element analysis worms (adults and juveniles) were washed with deionized water, placed on filter paper to allow to clear their gastrointestinal tracts for $24 \mathrm{~h}$. Than worms were dried at $60^{\circ} \mathrm{C}$ for at least $24 \mathrm{~h}$. The dried earthworms were digested with $3 \mathrm{~mL}$ of $\mathrm{HNO}_{3}(65 \%)$ and $1 \mathrm{~mL}$ of $\mathrm{H}_{2} \mathrm{O}_{2}(30 \%)$ using a microwave digestion system (Milestone Ethos One). The concentrations of trace elements $(\mathrm{Pb}, \mathrm{Cu}, \mathrm{Fe}$, $\mathrm{Ni}, \mathrm{Sb}, \mathrm{Mn}$, and $\mathrm{Zn}$ ) were determined using ICP-OES (Perkin-Elmer, Optima 8000). The accumulated trace elements in the earthworm's tissues were analyzed in terms of total bioaccumulation factors (BAFs). Bioconcentration factor (BAF) was calculated dividing element concentrations in the tissue by the total concentrations in soil.

\subsection{Biochemical assays}

Prior to freezing, earthworms were washed with deionized water and placed on filter paper to clear their gastrointestinal tracts for $24 \mathrm{~h}$. Three frozen worms from each replicate were used for analysis of the glutathione S-transferase (GST), catalase (CAT), and glutathione reductase (GR) activities. Tissues (0.15 $0.20 \mathrm{~g}$ ) were homogenized in a $1.5 \mathrm{ml}$ elution extraction buffer containing $200 \mathrm{ml}$ potassium phosphate buffer ( $\mathrm{pH} 7.8), 61.72 \mathrm{mg}$ dichloro-diphenyl-trichloroethane $+5.8 \mathrm{mg}$ ethylenediaminetetraacetic acid, $1 \mathrm{~g}$ polyethylene glycol 4000, $2 \mathrm{~g}$ polyvinylpolypyrrolidone. The homogenate was centrifuged at 13,000 rpm $\left(4{ }^{\circ} \mathrm{C}\right)$ to obtain the supernatant for the assay of GST, CAT, and GR.

GR reaction was based on nicotinamide adenine dinucleotide phosphate oxidase (NADPH) oxidation when GR reduces glutathione disulfide (GSSG). NADPH concentration was estimated at 340 nm (Esterbauer and Grill 1978; Bailly et al. 1996).

Catalase activities were measured with $\mathrm{H}_{2} \mathrm{O}_{2}$ substrate (Bailly et al. 1996; Claiborne 2018). The decrease in hydrogen peroxide was determined by reading absorption at $240 \mathrm{~nm}$ of extract prepared from $0.05-0.1 \mathrm{~g}$ E. fetida tissue homogenized with $1.5 \mathrm{ml}$ potassium phosphate buffer (pH 7.8). Extract was homogenized at $600 \mathrm{rpm}$ for $5 \mathrm{~min}$, at 13,000 rpm for $30 \mathrm{~min}$, and at 30,000 rpm for $105 \mathrm{~min}$.

GST was determined by homogenizing earthworm sample with $50 \mathrm{mM}$ potassium phosphate buffer $(1 \mathrm{ml}, \mathrm{pH}=7)$ and based on measuring GSH conjugation with 1-chlor-2,4-dinitrobenzene at 340 $\mathrm{nm}$. 
Total protein contents were determined according to the Bradford method (1976). Homogenate (with potassium phosphate buffer) was centrifuged at $13,000 \mathrm{rpm}$ for $15 \mathrm{~min}$ at $4{ }^{\circ} \mathrm{C}$. Bradford reagent was diluted with water (1:5). Absorption was measured at $660 \mathrm{~nm}$.

Lipid peroxidation (MDA) was determined using $50 \mu$ protein extract (Bradford 1976), $700 \mu \mathrm{l} 10$ $\mathrm{mM}$ thiobarbituric acid, and $10 \mu \mathrm{l} 2 \%$ butylated hydroxyanisole followed by $15 \mathrm{~min}$ incubation at $100^{\circ} \mathrm{C}$ and 5 min centrifugation at $13,000 \mathrm{rpm}$. The absorption of the supernatant was determined at 440,532 , and $600 \mathrm{~nm}$.

\subsection{Statistical analysis}

The values of trace elements in soil were normalized using a $\log (\mathrm{x})$ transformation. A Tukey's HSD test was used to determine differences among means of variables at the $95 \%$ confidence level. Multiple linear regression models were conducted to determine the relationship between the endpoints of earthworms and the physicochemical soil properties. The software package STATISTICA 10 was used for the statistical analyses, and GraphPad Prism 8.4.3 was used for the graphical representation.

\section{Results}

\subsection{Soil physical and chemical characteristics}

More than half of the soil mass contained bullets at site D (at $45 \mathrm{~m}$ from the fire line), $554 \mathrm{~g}$ from $1000 \mathrm{~g}$ of the soil (Table 1). Site $D$ is strongly influenced by direct impact of bullets and ricochet because this site is located at the end of the range. Soil density was higher and inorganic phosphorus $(P)$ content was lower at this site compared with the reference. The $\mathrm{pH}$ of the shooting range soil varied from 6.60 to 7.14 and there were no significant differences compared to the reference soil $(p>0.05)$. Soil organic matter content was significantly lower among all field soil samples compared to reference soil $(p<0.05)$.

Total $\mathrm{Pb}$ concentrations in the shooting field soils ranged from 217 to $53,023 \mathrm{mg} \mathrm{kg}^{-1}$ (Table 1 ). The shooting range soils contained elevated lead concentrations compared to the background (15 mg kg-1) and maximum (100 $\mathrm{mg} \mathrm{kg}^{-1}$ ) lead concentrations in Lithuanian soils (HN 60:2004). Significantly higher level of total lead was observed in all sites of the shooting range compared to reference $(p<0.05)$, and the highest levels of lead were observed at site $D\left(53022 \mathrm{mg} \mathrm{kg}^{-1}\right)$. Studies show that shooting range area contamination with lead is extremely high in shooting ranges - even up to $81,000 \mathrm{mg} \mathrm{kg}^{-1}$ (in stop berm soil) and $21,000 \mathrm{mg} \mathrm{kg}^{-1}$ in the range areas (Sanderson et al., 2010). Heavy contamination in Sb was also characteristic of site $D\left(599 \mathrm{mg} \mathrm{kg}^{-1}\right)$ while its concentration was below the detection level in other study sites. Nickel concentrations were significantly higher in all sites than the reference $(p<0.05)$ except site $\mathrm{C}$. At the most contaminated shooting range site (site $\mathrm{D}$ ), the soil was contaminated with $\mathrm{Pb}$ and Sb. Vegetation could reduce lead leaching (Fayiga and Saha 2016), and phosphorus is one of the nutrients for plants. Vegetation was almost absent at the end of the shooting range. Therefore, total $\mathrm{Pb}$ concentration was negatively correlated with phosphorus content in soil $(r=-0.56, p<0.05)$. The soil bulk 
density was positively related to the mass of the sieved bullets $(r=0.75, p<0.05)$, indicating the direct bullet impact on soil. The largest number of sieved bullets was present at the end of the shooting range (near to the target lines). We could suggest that, when reaching the ground, the bullet tears the soil layer, which contributes to changes in soil properties, in this case, the soil density.

\subsection{Toxicity test and bioaccumulation of trace elements}

After 4 weeks, exposure and mortality of E.fetida were lower than $10 \%$, even in site D where soil is heavily contaminated with $\mathrm{Pb}$, but there was no significantly higher mortality of E.fetida in the shooting range soils compared to reference ( $p>0.05$ ) (Fig. 1). Over 28 days, significantly lower weight of earthworms (E.fetida) exposed to the contaminated soils of the shooting range was observed $(p<0.05 ;$ Fig. 1$)$. The weight loss ranged from $5.8-6.6 \%$ at sites $A$ and $B$ to about $44.4 \%$ at site $D$. At site D, no juvenile $E$. fetida were produced when exposed to the soil, and no significant differences of juvenile production were observed between reference and other sites (Fig. 1).

$\mathrm{Pb}$ concentration in earthworm tissues was significantly higher in all soil samples of the shooting range than the reference $(p<0.05)$ with the highest bioaccumulation $\left(3101 \mathrm{mg} \mathrm{kg}^{-1}\right)$ at site $\mathrm{D}$ (Fig. 2). Significantly higher concentrations of $\mathrm{Cu}$ were determined only in adults exposed to soil from site $\mathrm{D}$ (Fig. 2). No significant differences of accumulation of $\mathrm{Cd}$ and $\mathrm{Zn}$ were observed among adult worms. Significantly higher $\mathrm{Fe}, \mathrm{Ni}$, and $\mathrm{Sb}$ concentration were observed in the adult worms exposed to site $\mathrm{D}(\mathrm{p}<$ 0.05 , Fig. 2). The lowest concentration of $\mathrm{Mn}$ was observed only in the tissues of adult earthworms exposed to site A soil (Fig. 2). Results indicated that $\mathrm{Pb}$ was accumulated in earthworms exposed to soils of the shooting range area, especially at the end of the shooting range (site $\mathrm{D})$, while other trace elements $(\mathrm{Cu}, \mathrm{Fe}, \mathrm{Ni}, \mathrm{Sb})$ were accumulated mostly only at the end of the range - there the contamination was the highest (at site $\mathrm{D}$ ).

The concentrations of $\mathrm{Pb}, \mathrm{Cu}, \mathrm{Fe}, \mathrm{Mn}, \mathrm{Sb}$, and $\mathrm{Zn}$ in juvenile tissues were significantly higher in all soil samples than the reference (Fig. 3). The highest concentration of $\mathrm{Pb}$ was observed in juveniles produced in soil from shooting range site $\mathrm{B}$. No significant differences were observed only on accumulation of $\mathrm{Ni}$ in juveniles of E.fetida (Fig. 3).

The total bioaccumulation factor (BAFs) of $\mathrm{Pb}$ in exposed earthworms ranged from 0.06 to 0.33 and were arranged in the following order: $B>C>A>D$ (Table 2). The BAFs in juveniles was slightly higher than in adults $(0.07-0.40)$ and were in the following order: $C>B>A$ (no juveniles were present in site $D$ ). Bioconcentration factor (BAF) of site $D$ among adults seem to be relatively low because of the extremely high total $\mathrm{Pb}$ concentration in soil.

\subsection{Relationship between E.fetida bioassay endpoints and soil properties}

Weight loss of E.fetida was significantly positively correlated with total Pb in the soil (Table 3). Lead accumulation in earthworms was significantly positively correlated with total lead concentration, while other soil properties had negligible effects on the accumulation of lead in the exposed organisms. Higher 
mortality was positively related with total $\mathrm{Mn}, \mathrm{Fe}$, and $\mathrm{Zn}$ concentrations in soil and negatively with $\mathrm{Cu}$ (Table 3).

\subsection{Biomarker responses of earthworm E. fetida to contaminated soil}

MDA concentration in all test samples of E.fetida was significantly higher than the reference $(p<0.05$; Fig. 4), but no significant correlation between MDA content and physicochemical properties was observed (Table 4). CAT activities showed no significant differences (Fig. 4).

Significantly higher activities of GR were determined in the earthworms exposed to soil from site $D$ compared to reference ( $p<0.05$; Fig. 4). Significant positive correlations were determined between GR activities and soil properties (Table 4). A positive linear correlation was observed between total $\mathrm{Pb}$ concentration, organic matter content in soil, and GR activities in earthworms $(r=0.71, p<0.05$ and $r=$ $0.73, p<0.05$, respectively). There was a positive linear correlation between weight loss and GR activities of E. fetida $(\mathrm{r}=0.71, \mathrm{p}<0.05)$. Also, $\mathrm{GR}$ activities of E.fetida were positively related to bioaccumulation of $\mathrm{Pb}$ and $\mathrm{Cu}$ in earthworms $(r=0.72, \mathrm{p}<0.05$ and $\mathrm{r}=0.83, \mathrm{p}<0.05$, respectively).

No significant tendency in GST (Fig. 4D) activities in adult earthworms at the end of the test was determined. In site D, where soil was heavily contaminated with lead, GST activity tended to be even lower than the other shooting range sites. Interestingly, negative correlation between GST activity of E.fetida and total $\mathrm{Pb}$ in soil, organic matter content in soil, weight loss of E. fetida, and bioaccumulation of $\mathrm{Pb}$ and $\mathrm{Cu}$ in $E$. fetida was determined ( $\mathrm{p}<0.05)$. Also, negative linear correlation between GR activity and GST activity in earthworms was determined, meaning that with the increase of GR activity, GST decreased ( $r=$ $0.76, p<0.05)$, indicating a compensatory mechanism between the activity of GR and GST.

\section{Discussion}

This study demonstrated that significant differences in soil properties - lower organic matter content and inorganic phosphorus, and higher soil density were characteristic for soil at the end of the shooting range (site D). According to Sehube et al. (2017), higher pH and organic matter content may contribute to the transformation of $\mathrm{Pb}$ into different weathering products, such as $\mathrm{PbO}, \mathrm{PbCO}_{3}, \mathrm{~Pb}_{3}\left(\mathrm{CO}_{3}\right)_{2}(\mathrm{OH})_{2}, \mathrm{PbSO}_{4}$, etc. Fayiga and Saha (2016) reported that lower moisture, lower organic matter, and higher pH contribute to lowered weathering of $\mathrm{Pb}$ in sands. Sanderson et al. (2019) also agreed that weathering decreases with lower organic matter because of lower soil moisture and $\mathrm{CO}_{2}$ level. Our results show that $\mathrm{SOM}$ in all sites of the shooting range is lower than the reference soil and $\mathrm{pH}$ is close to neutral over the shooting range area. Therefore, we could assume the majority of metallic lead in soil is in stable form. As was expected, high lead concentrations, up to $53,000 \mathrm{mg} \mathrm{kg}^{-1}$, were present in the soil with the highest contamination at the end of the range. High antimony concentration (almost $600 \mathrm{mg} \mathrm{kg}^{-1}$ ) was present at this site. These results are in agreement with other studies. Fayiga and Saha (2016) reported total lead concentrations in the range from 10,068 to $70,350 \mathrm{mg} \mathrm{kg}^{-1}$ among the different shooting sites. Sanderson et al. (2018) stated that for the target ranges, like the one in our study, the highest contamination appears in 
the fallout zone, closest to site D in this case. Cao et al. (2003) agreed that with increasing distance from the firing line, $\mathrm{Pb}$ concentration increases. These assumptions confirm that the primary problem of shooting range contamination is enormous amounts of lead, especially at the end of the range, near the target lines.

Although no mortality was observed, which agrees with Booth (2003), growth of E. fetida was a sensitive indicator of soil toxicity to earthworms. Extreme weight loss (44\%) was observed in heavily leadcontaminated soil from site D. Significant weight loss of the earthworms occurred at concentrations of 216 - $443 \mathrm{mg} \mathrm{kg}^{-1}$ of total $\mathrm{Pb}$ in soil. Although Luo et al. (2014b) observed that no significant weight loss of earthworms occurred in soil where $\mathrm{Pb}$ concentrations were up to $656 \mathrm{mg} \mathrm{kg}^{-1}$. The results highlighted that site-specific conditions could modify the effects of soil contamination on the survival of earthworms. Severe weight loss is a key component that could lead to a decrease in a whole population of these essential organisms. Similar assumptions were represented by Uwizeyimana et al. (2017) after earthworm exposition to nickel. In our case, $\mathrm{Pb}$ is the primary contaminant, and the results of regression analysis confirmed this.

$\mathrm{Pb}$ was accumulated in both studied life stages of earthworms (juveniles and adults), and the uptake was higher than that of any other elements. Earthworms exposed to the soil from the end of the range (site $D$ ) at the adult stage accumulated significant amounts of $\mathrm{Cu}, \mathrm{Fe}, \mathrm{Ni}$ and $\mathrm{Zn}(\mathrm{p}<0.05)$, juveniles $-\mathrm{Cu}, \mathrm{Fe}, \mathrm{Zn}$, and $\mathrm{Mn}(\mathrm{p}<0.05)$, but relatively lower compared to the accumulated concentrations of $\mathrm{Pb}$. Other studies demonstrated that earthworms exposed to shooting range soil contamination accumulated $\mathrm{Pb}$ in the range from 190 to $2,210 \mathrm{mg} \mathrm{kg}^{-1}$ in different shooting ranges. Accumulation of other elements $(\mathrm{Zn}, \mathrm{Cu})$ is much lower compared to $\mathrm{Pb}$, but it is still relatively high (Sanderson et al. 2014). Alternatively, Luo et al. (2014b) suggested that $\mathrm{Pb}$ concentration of in worms increases significantly when soil concentration of $\mathrm{Pb}$ is over $88 \mathrm{mg} \mathrm{kg}^{-1}$, and this study strongly agrees with our results, as the higher uptake of $\mathrm{Pb}$ was observed in the most contaminated soil. Our analyses suggest that uptake of lead can be predicted only on total lead concentration in soil.

Our results indicated that malondialdehyde (MDA) is a very sensitive indicator of lipid peroxidation and reflects cellular oxidative damage, especially with increased doses of $\mathrm{Pb}$ which agrees with other studies (Bai et al. 2020). Similarly, Li et al. (2020) suggested that over 14 days, response of this biomarker is more sensitive compared to 28 days (duration of our test). Due to mixed trace elements contamination in our experiment, observation of other effects (weight loss, mortality) emerging over longer duration was also important during this test. Hu et al. (2016) and Sinkakarimi et al. (2020) illustrated a dose-response pattern on MDA with $\mathrm{Pb}$ exposure, although our results cannot confirm this. Our results reflect a similar tendency, as the site $D$ (soil 53,022 $\mathrm{Pb} \mathrm{mg} \mathrm{kg}^{-1}$ ) earthworms contained higher MDA content than site $A$ (soil $443 \mathrm{~Pb} \mathrm{mg} \mathrm{kg}^{-1}$ ) and the reference soil $\left(25 \mathrm{~Pb} \mathrm{mg} \mathrm{kg}^{-1}\right)$. The highest MDA content with the highest $\mathrm{Pb}$ concentration in soil was determined similarly to Sinkakarimi et al. (2020) where the highest MDA percentage change was observed in a 28-day period. Absence of CAT activities could be associated with high cellular stress under which CAT activity can decrease with exposure time (Chao et al., 2016). Longer 
experimental duration might be associated with defined nonsignificant changes in catalase (CAT) activities in our study. Similarly, Chao et al. (2016) proposed that the reason for nonsignificant changes in CAT might be associated with high cellular stress under which CAT activity can decrease with exposure time. In our study, CAT activity was too sensitive as an indicator for higher duration testing. With increasing total $\mathrm{Pb}$ concentration and organic matter in soil, GR activity of earthworms E. fetida also increased. A significant increase in GR activity was observed only in site $\mathrm{D}$, where $\mathrm{Pb}$ and $\mathrm{Sb}$ contamination was the highest. Although we cannot predict GR activity, there is a positive correlation between $\mathrm{GR}$ and total $\mathrm{Pb}$ concentration, organic matter, weight loss, and bioaccumulation of $\mathrm{Pb}$ and $\mathrm{Cu}$ in the tissues of earthworms. Consequently, we can infer that GR activities increased with increased weight loss, bioaccumulation of $\mathrm{Pb}$ and $\mathrm{Cu}$ in $\mathrm{E}$. fetida $\mathrm{GR}$ activities increased. Studies show that glutathione in cellular tissue has a protective function against toxicity provoked by trace elements and $\mathrm{Pb}$ doses significantly affect GR and GST activity (Maity et al. 2008). In our case, GST activity was the lowest where the concentration of $\mathrm{Pb}$ in soil was the highest, a even negative relationship between GR and GST was even present. This study clearly indicated a compensatory mechanism between GR and GST. Łaszczyca et al. (2004) reported that in the site with total trace elements concentrations in soil of $\mathrm{Zn}-$ $5,104 \mu \mathrm{g} \mathrm{g}^{-1} ; \mathrm{Cd}-51 \mu \mathrm{g} \mathrm{g}^{-1} ; \mathrm{Cu}-38 \mu \mathrm{g} \mathrm{g}^{-1} ; \mathrm{Pb}-1,832 \mu \mathrm{g} \mathrm{g}^{-1}$, the earthworms E. fetida accumulated a total of $450 \mu \mathrm{g} \mathrm{Zn} \mathrm{g}^{-1}, 8 \mu \mathrm{g} \mathrm{Pb} \mathrm{g}^{-1}, 96 \mu \mathrm{g} \mathrm{Cd} \mathrm{g}^{-1}, 12 \mu \mathrm{g} \mathrm{Cu} \mathrm{g}^{-1}$. Under these conditions, authors reported the highest GR activity but the lowest activity of glutathione peroxidase and GST in the earthworms taken directly from the contaminated site. Results suggest that this kind of mechanism appears because of induced changes between reduced and oxidized glutathione; this causes an increased consumption of this peptide for synthesis of trace elements, binding proteins (Łaszczyca et al. 2004).

\section{Conclusions}

Our results showed that trace element contamination was particularly characteristic to the site at the end of the shooting range due to highest direct impact of bullets and ricochet. High concentrations of $\mathrm{Pb}$ and other trace elements ( $\mathrm{Cu}, \mathrm{Cd}, \mathrm{Fe}, \mathrm{Zn}, \mathrm{Ni}, \mathrm{Sb}, \mathrm{Mn}$ ) had a significant negative impact on the growth and reproduction of the earthworms. Earthworms accumulated trace elements from the contaminated soil, resulting in a significant impact on their enzyme system. MDA was a very sensitive indicator of lipid peroxidation, but GR activity was observed only in the earthworms exposed to the soil from the most contaminated site. Also, a compensatory mechanism between GR and GST was suggested because of the negative relationship between these biomarkers. The effect of contaminated shooting range soil on earthworms' molecular biomarkers should be studied using a longer exposure period.

\section{Declarations}

\section{Acknowledgements}

The authors are thankful to Diana Miškelyte for the assistance in the laboratory analysis. 
Authors' contributions Conceptualisation; methodology; investigation; data collection; visualisation; writing - original draft: J.Č. Laboratory analysis: M.P. Laboratory analysis, conceptualisation, editing: N.P. Writing - review and editing, and paper administration: G.S. All the authors commented on previous versions of the manuscript. All the authors read and approved the final manuscript.

Funding This work was supported by Vytautas Magnus university by a research grant (no. P-G-19-04).

Data availability The datasets used and/or analyzed during the current study are available from the corresponding author on reasonable request.

\section{Compliance with ethical standards}

Competing interests The authors declare that they have no competing interests.

Ethics approval and consent to participate Not applicable

Consent for publication Not applicable

\section{References}

Baer KN, Hutton DG, Boeri RL, et al (1995) Toxicity evaluation of trap and skeet shooting targets to aquatic test species. Ecotoxicology 4:385-392. https://doi.org/10.1007/BF00118873

Bai H, Luo M, Wei S, et al (2020) The vital function of humic acid with different molecular weight in controlling $\mathrm{Cd}$ and $\mathrm{Pb}$ bioavailability and toxicity to earthworm (Eisenia fetida) in soil. Environmental Pollution 261:114222. https://doi.org/10.1016/j.envpol.2020.114222

Bailly C, Benamar A, Corbineau F, Come D (1996) Changes in malondialdehyde content and in superoxide dismutase, catalase and glutathione reductase activities in sunflower seeds as related to deterioration during accelerated aging. Physiologia Plantarum 97:104-110. https://doi.org/10.1111/j.13993054.1996.tb00485.x

Bradford MM (1976) A rapid and sensitive method for the quantitation of microgram quantities of protein utilizing the principle of protein-dye binding. Analytical Biochemistry 72:248-254. https://doi.org/10.1016/0003-2697(76)90527-3

Cao X, Ma LQ, Chen M, et al (2003) Weathering of lead bullets and their environmental effects at outdoor shooting ranges. Journal of Environmental Quality 32:526-534. https://doi.org/10.2134/jeq2003.5260

Chao G, Jingbo X, Ji L, Zhengtao L (2016) Biological responses in the earthworm Eisenia fetida exposed to soils near a typical lead acid battery plant. Soil and Sediment Contamination 25:573-585. https://doi.org/10.1080/15320383.2016.1184619

Claiborne A (2018) Handbook Methods For Oxygen Radical Research. CRC Press 
Dinake P, Kelebemang R, Sehube N (2019) A comprehensive approach to speciation of lead and its contamination of firing range soils: A review. Soil and Sediment Contamination 28:431-459. https://doi.org/10.1080/15320383.2019.1597831

Esterbauer H, Grill D (1978) Seasonal variation of glutathione and glutathione reductase in needles of Picea abies. Plant Physiology 61:119-121. https://doi.org/10.1104/pp.61.1.119

Fayiga AO, Saha UK (2016) Soil pollution at outdoor shooting ranges: Health effects, bioavailability and best management practices. Environmental Pollution 216:135-145.

https://doi.org/10.1016/j.envpol.2016.05.062

HARDISONJR D, MA L, LUONGO T, HARRIS W (2004) Lead contamination in shooting range soils from abrasion of lead bullets and subsequent weathering. Science of The Total Environment 328:175-183. https://doi.org/10.1016/j.scitotenv.2003.12.013

Hood-Nowotny R, Umana NH-N, Inselbacher E, et al (2010) Alternative methods for measuring inorganic, organic, and total dissolved nitrogen in soil. Soil Science Society of America Journal 74:1018-1027. https://doi.org/10.2136/sssaj2009.0389

Hu S, Zhang W, Li J, et al (2016) Antioxidant and gene expression responses of Eisenia fetida following repeated exposure to BDE209 and Pb in a soil-earthworm system. Science of The Total Environment 556:163-168. https://doi.org/10.1016/j.scitotenv.2016.02.194

Łaszczyca P, Augustyniak M, Babczyńska A, et al (2004) Profiles of enzymatic activity in earthworms from zinc, lead and cadmium polluted areas near Olkusz (Poland). Environment International 30:901910. https://doi.org/10.1016/j.envint.2004.02.006

Li C, Zhou K, Qin W, et al (2019) A Review on Heavy metals contamination in soil: Effects, sources, and remediation techniques. Soil and Sediment Contamination 28:380-394.

https://doi.org/10.1080/15320383.2019.1592108

Li X, Wang M, Jiang R, et al (2020) Evaluation of joint toxicity of heavy metals and herbicide mixtures in soils to earthworms (Eisenia fetida). Journal of Environmental Sciences 94:137-146.

https://doi.org/10.1016/j.jes.2020.03.055

Luo W, Verweij RA, van Gestel CAM (2014a) Determining the bioavailability and toxicity of lead contamination to earthworms requires using a combination of physicochemical and biological methods. Environmental Pollution 185:1-9. https://doi.org/10.1016/j.envpol.2013.10.017

Luo W, Verweij RA, van Gestel CAM (2015) Toxicity of Pb contaminated soils to the oribatid mite Platynothrus peltifer. Ecotoxicology. https://doi.org/10.1007/s10646-015-1439-3

Luo W, Verweij RA, van Gestel CAM (2014b) Assessment of the bioavailability and toxicity of lead polluted soils using a combination of chemical approaches and bioassays with the collembolan Folsomia 
candida. Journal of Hazardous Materials 280:524-530. https://doi.org/10.1016/j.jhazmat.2014.08.044

Luo W, Verweij RA, van Gestel CAM (2014c) Contribution of soil properties of shooting fields to lead biovailability and toxicity to Enchytraeus crypticus. Soil Biology and Biochemistry 76:235-241. https://doi.org/10.1016/j.soilbio.2014.05.023

Maity S, Roy S, Chaudhury S, Bhattacharya S (2008) Antioxidant responses of the earthworm Lampito mauritii exposed to $\mathrm{Pb}$ and $\mathrm{Zn}$ contaminated soil. Environmental Pollution 151:1-7. https://doi.org/10.1016/j.envpol.2007.03.005

OECD (2015) OECD 222 - Earthworm Reproduction Test (Eisenia fetida/Eisenia andrei). The Organisation for Economic Co-operation and Development (OECD). https://doi.org/10.1787/9789264067394-eng

Owagboriaye FO, Dedeke GA, Ademolu KO (2016) Glutathione-S-transferase production in earthworm as tool for assessment of heavy metal pollution in Abattoir soil. Revista de Biología Tropical 64:779. https://doi.org/10.15517/rbt.v64i2.18484

Petitou M, Tuy F, Rosenfeld C (1978) A simplified procedure for organic phosphorus determination from phospholipids. Analytical Biochemistry 91:350-353. https://doi.org/10.1016/0003-2697(78)90849-7

Reid BJ, Watson R (2005) Lead tolerance in Aporrectodea rosea earthworms from a clay pigeon shooting site. Soil Biology and Biochemistry 37:609-612. https://doi.org/10.1016/j.soilbio.2004.09.003

Rodríguez-Seijo A, Cachada A, Gavina A, et al (2017) Lead and PAHs contamination of an old shooting range: A case study with a holistic approach. Science of The Total Environment 575:367-377. https://doi.org/10.1016/j.scitotenv.2016.10.018

Sanderson P, Naidu R, Bolan N, et al (2012) Effect of soil type on distribution and bioaccessibility of metal contaminants in shooting range soils. Science of The Total Environment 438:452-462. https://doi.org/10.1016/j.scitotenv.2012.08.014

Sanderson P, Naidu R, Bolan N (2014) Ecotoxicity of chemically stabilised metal(loid)s in shooting range soils. Ecotoxicology and Environmental Safety 100:201-208.

https://doi.org/10.1016/j.ecoenv.2013.11.003

Sanderson P, Qi F, Seshadri B, et al (2018) Contamination, fate and management of metals in shooting range soils - A review. Current Pollution Reports 4:175-187. https://doi.org/10.1007/s40726-018-0089-5

Sanderson P, Thangavadivel K, Ranganathan S, et al (2019) Effectiveness of gravity based particle separation and soil washing for reduction of $\mathrm{Pb}$ in a clay loam shooting range soil. Environmental Technology \& Innovation 16:100480. https://doi.org/10.1016/j.eti.2019.100480

Sehube N, Kelebemang R, Totolo O, et al (2017) Lead pollution of shooting range soils. South African Journal of Chemistry 70:21-28. https://doi.org/10.17159/0379-4350/2017/v70a4 
Selonen S, Liiri M, Setälä H (2014) Can the soil fauna of boreal forests recover from lead-derived stress in a shooting range area? Ecotoxicology 23:437-448. https://doi.org/10.1007/s10646-014-1210-1

Sinkakarimi MH, Solgi E, Hosseinzadeh Colagar A (2020) Interspecific differences in toxicological response and subcellular partitioning of cadmium and lead in three earthworm species. Chemosphere 238:124595. https://doi.org/10.1016/j.chemosphere.2019.124595

Sneddon J, Clemente R, Riby P, Lepp NW (2009) Source-pathway-receptor investigation of the fate of trace elements derived from shotgun pellets discharged in terrestrial ecosystems managed for game shooting. Environmental Pollution 157:2663-9. https://doi.org/10.1016/j.envpol.2009.05.004

Sorvari J (2011) Shooting Ranges: Environmental Contamination. In: Encyclopedia of Environmental Health. Elsevier, pp 41-50

Sujetovienè G, Česynaitè J (2019) Assessment of toxicity to earthworm Eisenia fetida of lead contaminated shooting range soils with different properties. Bulletin of Environmental Contamination and Toxicology 103:. https://doi.org/10.1007/s00128-019-02695-x

Uwizeyimana H, Wang M, Chen W, Khan K (2017) The eco-toxic effects of pesticide and heavy metal mixtures towards earthworms in soil. Environmental Toxicology and Pharmacology 55:20-29. https://doi.org/10.1016/j.etap.2017.08.001

\section{Tables}

Table 1. Basic physicochemical properties and concentrations $(\mathrm{mg} / \mathrm{kg})$ of trace elements (mean \pm SE) of the studied shooting range soils (A, B, C, D) at different distances from the fire line $(5,20,30,45 \mathrm{~m}$, respectively) and reference soil. The different lower letters indicated significant differences between the treatments $(p<0.05)$, bdl: below detection limit. 


\begin{tabular}{|c|c|c|c|c|c|}
\hline & \multicolumn{4}{|c|}{ Field soil } & \multirow[t]{2}{*}{ Reference } \\
\hline & A & B & $\mathrm{C}$ & $\mathrm{D}$ & \\
\hline Sieved & $8.98 \pm 1.74 b$ & $2.34 \pm 0.26 b$ & $5.67 \pm 0.28 b$ & $554.44 \pm 16.25 b$ & $0 \mathrm{a}$ \\
\hline \multicolumn{6}{|l|}{ bullets } \\
\hline \multicolumn{6}{|l|}{ (g) } \\
\hline $\mathrm{pH}_{\mathrm{H} 2 \mathrm{O}}$ & $7.14 \pm 0.03 a$ & $6.60 \pm 0.04 b$ & $6.89 \pm 0.04 \mathrm{c}$ & $7.06 \pm 0.05 \mathrm{ac}$ & $7.14 \pm 0.01 \mathrm{a}$ \\
\hline $\mathrm{OM}$ & $6.21 \pm 0.11 b$ & $5.37 \pm 0.06 \mathrm{bc}$ & $5.41 \pm 0.08 \mathrm{bd}$ & $7.20 \pm 0.38 a$ & $8.14 \pm 0.25 a$ \\
\hline \multicolumn{6}{|l|}{ (\%) } \\
\hline Soil & $4.90 \pm 0.03 b$ & $5.30 \pm 0.16 b$ & $5.34 \pm 0.21 b$ & $6.14 \pm 0.21 b$ & $4.81 \pm 0.15 a$ \\
\hline \multicolumn{6}{|l|}{ density } \\
\hline \multicolumn{6}{|l|}{$\left(\mathrm{g} / \mathrm{cm}^{3}\right)$} \\
\hline $\mathrm{NH}_{4}^{+}{ }_{-}^{-}$ & $9.89 \pm 0.74 a$ & $11.04 \pm 1.13 a$ & $13.44 \pm 1.82 \mathrm{a}$ & $11.85 \pm 2.62 \mathrm{a}$ & $8.84 \pm 0.41 \mathrm{a}$ \\
\hline \multicolumn{6}{|l|}{$\mathrm{N}$} \\
\hline $\mathrm{NO}_{3}^{-}-$ & $20.7 \pm 1.50 \mathrm{a}$ & $16.1 \pm 1.85 b$ & $16.1 \pm 1.67 \mathrm{~b}$ & $2.3 \pm 0.88 c$ & $20.7 \pm 1.85 a$ \\
\hline \multicolumn{6}{|l|}{$\mathrm{N}$} \\
\hline Total P & $11.30 \pm 0.88 c$ & $7.01 \pm 0.47 \mathrm{ae}$ & $10.31 \pm 0.10 \mathrm{bc}$ & $4.99 \pm 0.35 \mathrm{de}$ & $8.44 \pm 0.21 \mathrm{ab}$ \\
\hline Total & $443.15 \pm 101.76 \mathrm{~cd}$ & $394.79 \pm 49.31 d$ & $216.66 \pm 73.91 \mathrm{acd}$ & $53,022.88 \pm 4030.83 b$ & $25.29 \pm 7.65 a$ \\
\hline \multicolumn{6}{|l|}{$\mathrm{Pb}$} \\
\hline Total & $24.03 \pm 4.75 \mathrm{ac}$ & $10.45 \pm 0.45 \mathrm{acd}$ & $6.07 \pm 1.79 \mathrm{bc}$ & $20.28 \pm 1.78 \mathrm{acd}$ & $41.00 \pm 7.56 \mathrm{ac}$ \\
\hline \multicolumn{6}{|l|}{$\mathrm{Cu}$} \\
\hline Total & $8,323.69 \pm 507.79 a$ & $5701.52 \pm 377.64 a$ & $4,948.25 \pm 358.54 a$ & $7,663.29 \pm 737.87 a$ & $7,785.24 \pm 358.25 a$ \\
\hline \multicolumn{6}{|l|}{$\mathrm{Fe}$} \\
\hline Total & $11.48 \pm 2.87 \mathrm{ac}$ & $5.04 \pm 0.53 a$ & $3.68 \pm 1.05 \mathrm{ac}$ & $8.18 \pm 0.45 a b c$ & $3.48 \pm 0.09 \mathrm{ac}$ \\
\hline \multicolumn{6}{|l|}{$\mathrm{Ni}$} \\
\hline Total & bdl & bdl & bdl & $599.78 \pm 79.57$ & bdl \\
\hline \multicolumn{6}{|l|}{$\mathrm{Sb}$} \\
\hline Total & $205.36 \pm 18.30 \mathrm{a}$ & $189.79 \pm 13.64 a$ & $169.68 \pm 10.21 \mathrm{a}$ & $214.94 \pm 19.07 a$ & $256.19 \pm 20.33 a$ \\
\hline Mn & $2.49 \pm 0.08 a$ & $2.02 \pm 0.12 b$ & $1.69 \pm 0.15 b c$ & $2.69 \pm 0.02 \mathrm{acd}$ & $2.71 \pm 0.04 a$ \\
\hline \multicolumn{6}{|l|}{ Total } \\
\hline $\mathrm{Zn}$ & & & & & \\
\hline
\end{tabular}

Table 2. Total bioconcentration factor (BAF) of trace elements in adults and juveniles of $E$. fetida exposed to shooting range soil. 


\begin{tabular}{llllllll}
\hline \multicolumn{1}{c}{ Bioconcentration factor (BAF) } \\
\hline & $\mathrm{Cu}$ & $\mathrm{Fe}$ & $\mathrm{Mn}$ & $\mathrm{Ni}$ & $\mathrm{Pb}$ & $\mathrm{Sb}$ & $\mathrm{Zn}$ \\
\hline A adults & 0.82 & 0.04 & 0.04 & 0.06 & 0.10 & - & 0.40 \\
A juveniles & 0.23 & 0.07 & 0.06 & 0.04 & 0.07 & - & 0.13 \\
B adults & 1.27 & 0.06 & 0.06 & 0.08 & 0.33 & - & 0.99 \\
B juveniles & 0.76 & 0.10 & 0.09 & 0.11 & 0.30 & - & 0.70 \\
C adults & 2.59 & 0.11 & 0.09 & 0.80 & 0.29 & - & 1.88 \\
C juveniles & 1.08 & 0.17 & 0.18 & 0.23 & 0.40 & - & 1.25 \\
D adults & 2.88 & 0.13 & 0.08 & 0.32 & 0.06 & 0.02 & 0.47 \\
Control adults & 0.18 & 0.04 & 0.04 & 0.05 & 0.12 & - & 0.24 \\
Control juveniles & 0.02 & 0.01 & 0.01 & 0.05 & 0.26 & - & 0.03 \\
\hline
\end{tabular}

Table 3. Multiple-regression equations and coefficient of determination $\left(\mathrm{R}^{2}\right)$ of relationships between physicochemical properties of soil and toxicity to earthworm E. fetida.

\begin{tabular}{lll}
\hline & Equation & Statistics \\
\hline Weight loss $(\mathrm{WL}, \%)$ & $\mathrm{WL}=15.36(\log [\mathrm{Pb}])-29.79$ & $\mathrm{R}^{2}=0.85, \mathrm{p}<$ \\
& & 0.01 \\
$\mathrm{~Pb}$ Accumulated & $\mathrm{Pb}_{\text {Accum }}=0.90(\log [\mathrm{Pb}])-0.63(\log [\mathrm{Zn}])+0.90$ & $\mathrm{R}^{2}=0.95, \mathrm{p}<$ \\
$(\mathrm{Pb}$ Accum $)$ & $\mathrm{Pb}_{\text {Accum }}=0.70 \log [\mathrm{Pb}]+0.13$ & 0.01 \\
& & $\mathrm{R}^{2}=0.89, \mathrm{p}<$ \\
& $\mathrm{M}=58.34(\log [\mathrm{Mn}])-35.88(\log [\mathrm{Fe}])-20.83(\log [\mathrm{Cu}])+12.12\left(\log \mathrm{R}^{2}=0.78, \mathrm{p}<\right.$ \\
Mortality $(\mathrm{M})$ & $[\mathrm{Zn}])+4.16$ & 0.01 \\
\hline
\end{tabular}

Table 4. Pearson correlation coefficient between biomarkers and soil properties and endpoints (n.s. - nonsignificant, $\mathrm{p}>0.05$ ).

\begin{tabular}{lccccc}
\hline & Total Pb & Organic matter & Weight loss & Bioaccumulation Pb & Bioaccumulation Cu \\
\cline { 2 - 5 } MDA & n.s. & n.s. & n.s. & n.s. & n.s. \\
CAT & n.s. & n.s. & n.s. & n.s. & n.s. \\
GR & $0.71, p=0.032$ & $0.73, p=0.025$ & $0.71, p=0.032$ & $0.72, p=0.028$ & $0.83 ; p=0.006$ \\
GST & $-0.97 ; p=0.000$ & $-0.87, p=0.011$ & $-0.89 ; p=0.008$ & $-0.89 ; p=0.007$ & n.s. \\
\hline
\end{tabular}

\section{Figures}



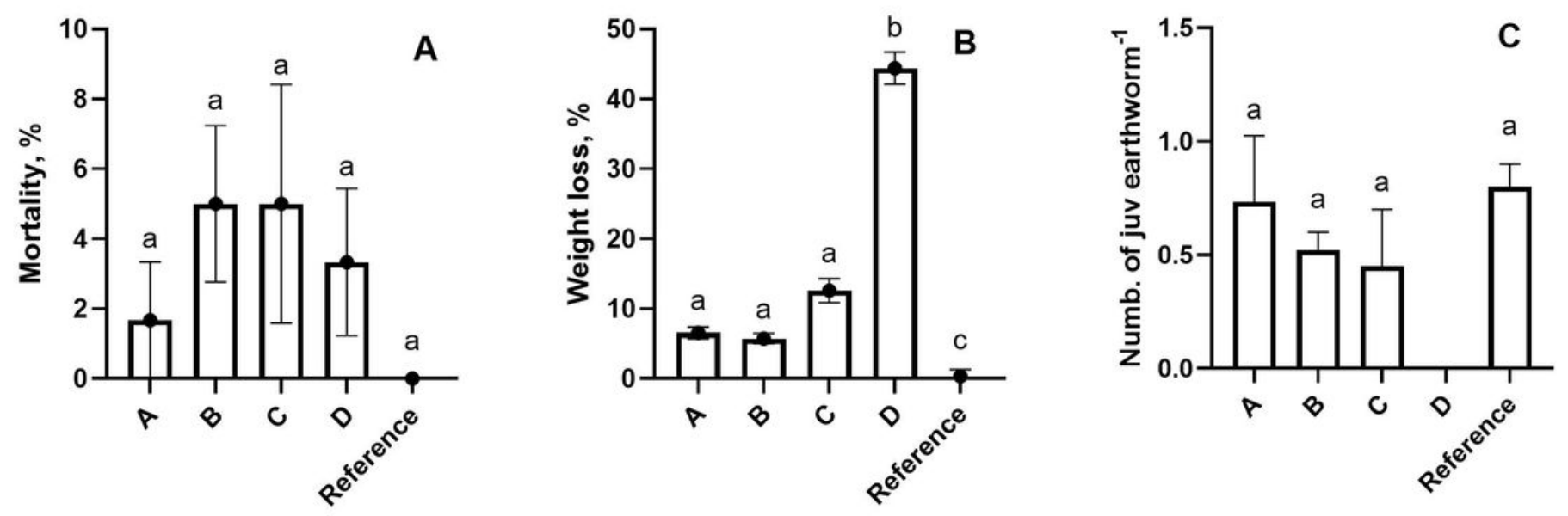

Figure 1

Mortality (A), weight loss (B) and number of juveniles (C) of earthworm (E. fetida) (mean \pm SE) after a 4week exposure to the shooting field soils $(A, B, C, D$ - plots at different distances from the fire line in the shooting range $(5,20,30,45 \mathrm{~m}$, respectively $))$. 

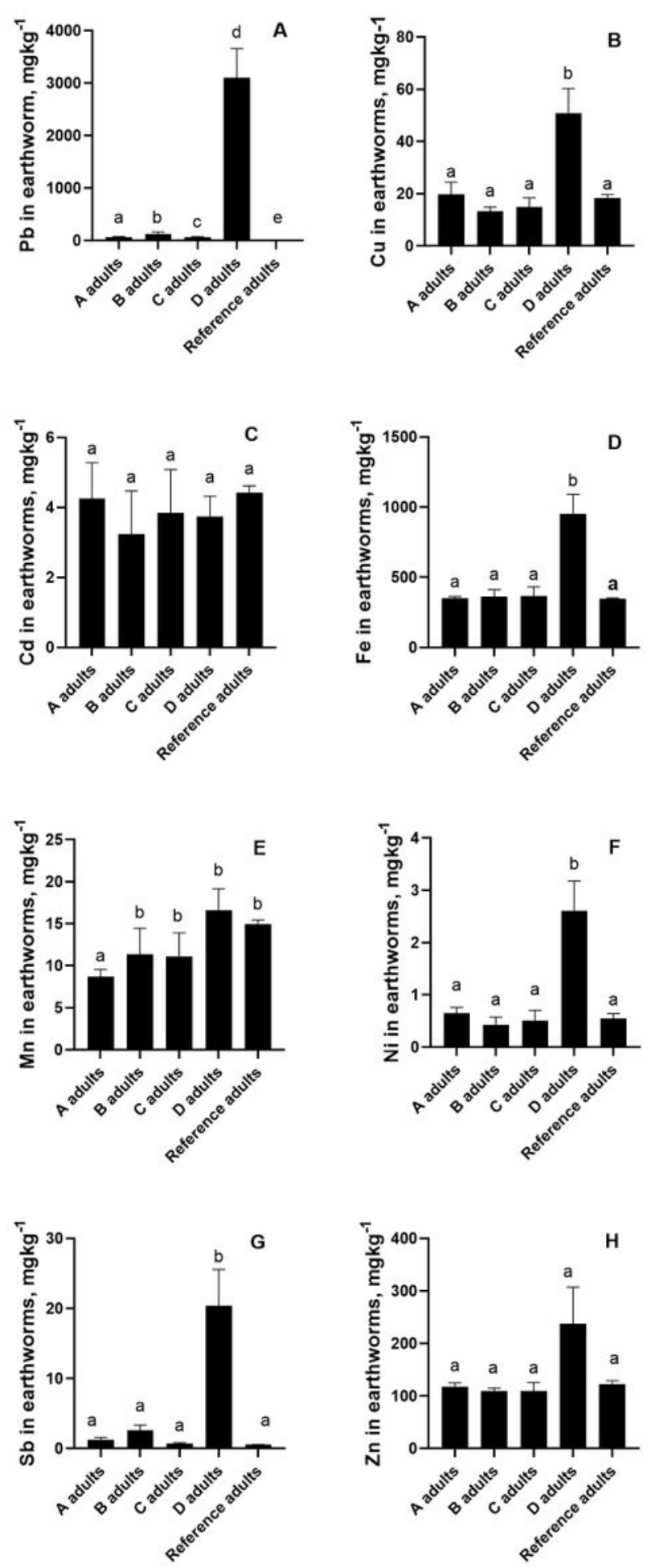

Figure 2

Tissue trace element concentrations in adults of E. fetida after a 4-week exposure to soils from the shooting range. $(A, B, C, D$ - plots at different distances from the fire line in the shooting range $(5,20,30$, and $45 \mathrm{~m}$, respectively)) 

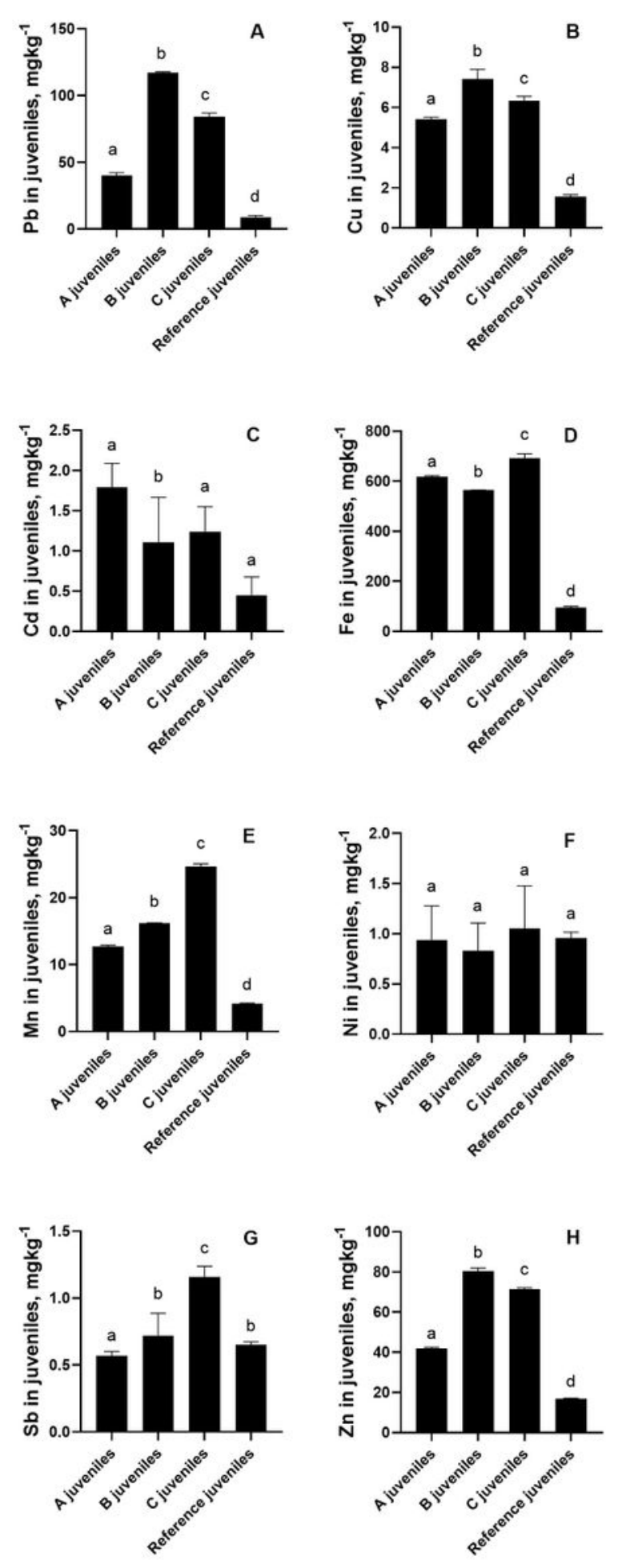

Figure 3

Tissue trace element concentrations in juveniles of E. fetida after a 4-week exposure to soils from the shooting range. (A, B, C, D - plots at different distances from the fire line in the shooting range $(5,20,30$, and $45 \mathrm{~m}$, respectively)) 


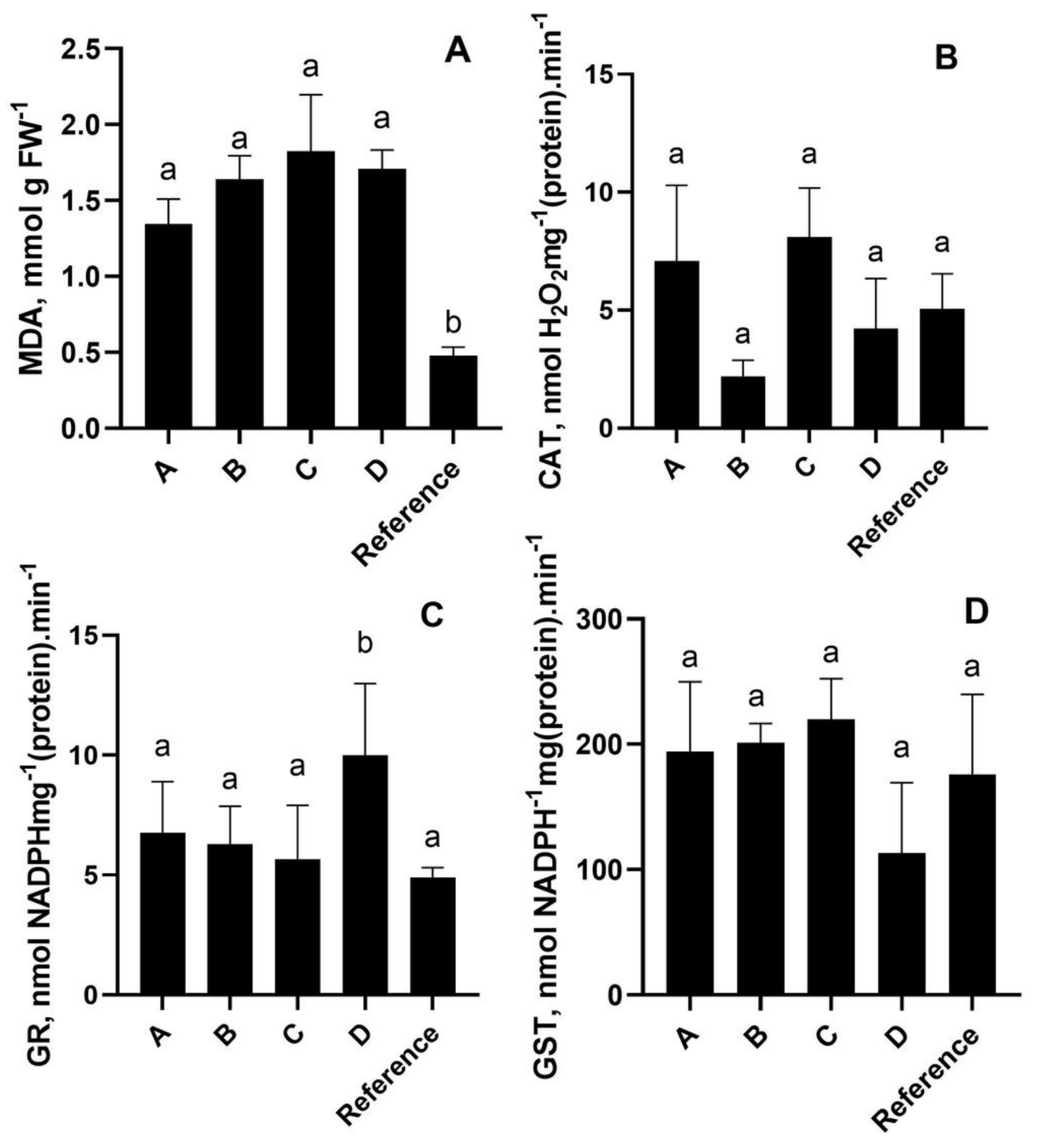

Figure 4

Lipid peroxidation (MDA) and activities of antioxidant enzyme (CAT, GR, GST) in earthworm E. fetida exposed to the shooting range soils. (A, B, C, D - plots at different distances from the fire line of the shooting range $(5,20,30$, and $45 \mathrm{~m}$, respectively) 